\title{
Production of high protein supplementary feed from landfill gas
}

\author{
Elena Klevanova*, and Alexander Lukanin \\ Peoples' Friendship University of Russia (RUDN University), Faculty of Ecology, 6 Miklukho- \\ Maklaya St, Moscow, 117198, Russian Federation
}

\begin{abstract}
The article describes the problem of feed protein deficiency. The main sources of the methane for the biomass production are considered. The chemical composition, the haprin main characteristics and its production technological scheme are presented. The solid municipal waste volume disposed of annually at the landfills is estimated. The quantitative characteristics of atmospheric pollutant emissions from the JSC "Polygon" landfill (Vladimir region) are presented. It is proposed to use landfill gas as the main raw material in the haprin production. The haprin amount obtained during the operation of the JSC "Polygon" landfill was calculated. The economic benefits of this production were estimated
\end{abstract}

\section{Introduction}

The intensification of animal agriculture requires a sharp increase in the production of feed protein compensating for its lack in the traditional vegetable feed. 30 million tons per year is the deficit of this product in the world, while in Russia the shortage of feed protein currently exceeds 2.5 million tons per year [1].

The main way to reduce and eliminate feed protein deficiency is to produce biomass using microbial synthesis: strains of methane-oxidizing (methanotrophs for example Methylomonas meyhanica, Methylobacter tundripaludum) and methane-producing (methanogen, for example, Methanococcus capsulatus bacteria). These bacteria have a record biomass accumulation rate thereby creating a large amount of protein. The biosynthesis process is less time-consuming and proceeds continuously regardless of the season and weather conditions while obtaining a protein that is stable in quality [2].

Currently experts from the different countries are actively studying the vital activity of the methanotrophic bacteria. For example, scientists from Calysta Inc. in California and String Bio in Bangalore (India) are developing new methods for converting methane to protein [2].

In Russia the largest producer of feed bacterial biomass from natural gas was the Svetloyarsk plant "Volgogradbiosytez" (Volgograd region). About 40.000 tons of haprin (short for "gas protein") were produced and sold during the period of its functioning from 1985 to 1994 . From 1996 to 2006 the Norwegian company Norferm produced a complete analog of the haprin called "bioprotein" for feeding fish and farm animals using Soviet

*Corresponding author: eklevanova@mail.ru 
technology. The Danish company UniBio for the pilot installation development of modified Soviet technology the production of the bio proteins under the name "UniPrin" ("uniprotein") for use in feed and food products [1].

\section{Materials and methods}

The haprin compositionally is a high-protein product containing in terms of absolutely dry substance at least $70 \%$ of crude protein and also having almost all essential amino acids (total not less than 55\%) (Table 1). The haprin also has lysine $4.0-5.3 \%$, sulfur-containing amino acids (serine, methionine) - 1.7\%. The haprin contains a large amount of vitamin B complex: thiamine (B1) - $14.1 \mathrm{mg} / \mathrm{kg}$, cyancobalamin (B12) - $5.6 \mathrm{mg} / \mathrm{kg}$ and micro and macro elements. Also it is non-toxic, does not have carcinogenic and cumulative effects [3].

Table 1. The amino acids included in the haprin.

\begin{tabular}{|l|c|l|c|}
\hline \multicolumn{1}{|c|}{ Amino acids } & Content, $\%$ & \multicolumn{1}{|c|}{ Amino acids } & Content, $\%$ \\
\hline lysine & $4.0-5.3$ & histidine & $1.7-2.5$ \\
\hline tryptophan & $1.4-1.6$ & aspartic acid & $5.3-5.8$ \\
\hline arginine & $2.3-3.5$ & threonine & $2.4-3.0$ \\
\hline serine & $1.2-2.3$ & glutamic acid & $6.8-7.8$ \\
\hline proline & $2.3-3.1$ & valine & $4.1-4.2$ \\
\hline alanine & $4.2-4.8$ & leucine & $4.5-4.9$ \\
\hline cystine & $0.3-0.5$ & phenylalanine & $2.3-2.9$ \\
\hline isoleucine & $2.6-3.0$ & methionine & $1.3-1.7$ \\
\hline tyrosine & $1.6-2.1$ & glycine & $3.0-3.8$ \\
\hline
\end{tabular}

The haprin is a full-fledged substitute for an animal protein in contrast to an animal feed (including cereals and legumes). It provides balanced amino acid nutrition of animals, birds and fish. For example it contains 5 times more protein than barley or oats. The haprin is superior to fishmeal and soybean meal in its nutritional value and balance in amino acid composition.

The haprin production is based on the implementation of cultivation processes in bioreactors of various designs using non-pathogenic strains of methane-assimilating cultures. The bacteria of the genus Methylomonas, Methylococcus, Methylocystts, Methulosinus, Methylobacter can be used as methane-assimilating cultures by continuously supplying oxygen-containing gas (the air, the oxygen-air mixture, the oxygen) and methane-containing gas (the natural gas, the methane) to the bioreactor. Further stages of processing the resulting biomass are traditional and include processes of concentrating cells from biosuspension, thermal sterilization and drying to obtain the finished product in the form of powder or granules $[4,5]$.

The technological process of obtaining haprin is continuous and consists of the following main stages:

1. The preparation of a nutrient substrate and the cultivation of seed pure culture.

2. The biomass fermentation.

3. The culture fluid separation.

4. The microbial suspension thickening.

5. The biomass inactivation.

6. Drying, packaging, packaging of the finished product.

7. Recycled process water purification.

To ensure the main technological process stages, auxiliary production stages are provided as part of the installation: reception, preparation of solutions and supply to the fermenters of ammonia water, phosphoric acid, salts and other chemicals in the required 
concentrations; preparation and supply of oxygen; cultivation of sowing "pure culture"; the exhaust gases conclusion of the fermentation process for disposal; purification of gas-air emissions at the stages of thickening, drying and packaging of the finished product; washing and disinfection of equipment.

Figure 1 shows a structural block diagram of one of the options for the biotechnological production of the haprin.

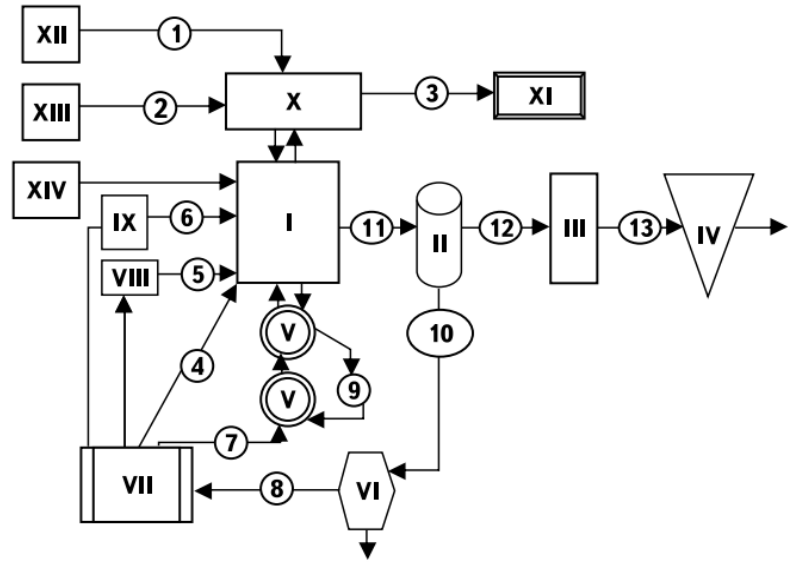

Fig. 1. Block diagram of the haprin production: streams: 1 - natural gas for cultivation; 2 oxygen source for cultivation; 3 - waste gas for energy utilization; 4 - process water for cultivation; 5 - culture medium solution for cultivation; 6 - ammonia-water solution for cultivation; 7 - circulating water to make up for losses; 8 - biologically purified water in the water treatment system; 9 - circulating water in the heat transfer system; 10 - waste cultured medium after concentration; 11 - biomass suspension from fermenters; 12 - concentrated biomass suspension for drying; 13 - commercial product. Stage: I - production fermentation; II - concentration (microfiltration and separation); III - drying; IV packaging; V - heat removal system; VI - effluents biological treatment; VII - water treatment system; VIII - the system for the preparation and supply of nutrient salts solution; IX - the system for preparing the supply of ammonia water; $X$ - gas-phase recirculation system; XI - exhaust gas utilization system; XII - the system for the preparation and supply of natural gas; XIII - the system of preparation and supply of an oxygen source; XIV sowing system.

The standard biotechnology for the methanotroph biomass production with a difference in some technological nuances can be based on various sources of methane, for example, from the gas pipeline system, from processing agricultural waste, from associated petroleum gas and others.

This article proposes the use of the methane of landfill gas (LG) landfills resulting from the biological conversion of organic substances with the participation of a methane-forming consortium of microorganisms in the landfill body, which causes odor rejection and harms people living in a radius of 500-1000 meters from the landfill [6]. Moreover, the process of organic waste fractions decomposition has been going on for many decades [7], which makes the landfill a stable LG source [8-10].

Nowadays in Russia there are more than 14 thousand large landfills with an area of more than 4 million hectares. These data are comparable with the sizes of some countries, for example, the area of Switzerland is 4.12 million ha, the Netherlands is 4.15 million ha, and the size of Slovenia ( 2 million ha) or Israel (2.2 million ha) is 2 times smaller.

The landfill gas is a mixture of gases, the main ones are $\mathrm{CH}_{4}$ (volume fraction - $45 \div$ $75 \%$ ), $\mathrm{CO}_{2}$ (volume fraction - $25 \div 55 \%$ ), $\mathrm{N}_{2}$ (up to $5 \%$, often over $10 \%$ ), $\mathrm{H}_{2} \mathrm{~S}, \mathrm{O}_{2}, \mathrm{H}_{2}$ and 
CO $[11,12]$. Moreover since the LG composition includes carbon dioxide before it is fed to the fermenter it is necessary to purify carbon dioxide.

As the study object for calculating the annual LG emissions from the landfill we took the JSC "Polygon" landfill $(55.930125,39.709838)$ located in the Vladimir Region on the border of the Petushinsky and Sobinsky districts about 3 kilometers from the village of Boldino and Babanino and 1.300 meters northwest of the M7 highway The Volga (Fig. 2).

The JSC "Polygon" landfill is a recess relatively isometric in shape a width of about 90 meters and elongated from west to east by about 150 meters.

This landfill began to operate on January 1, 2015. The amount of waste disposed per day is 1000 tons. The landfill area in the modern kennel is 17 hectares.

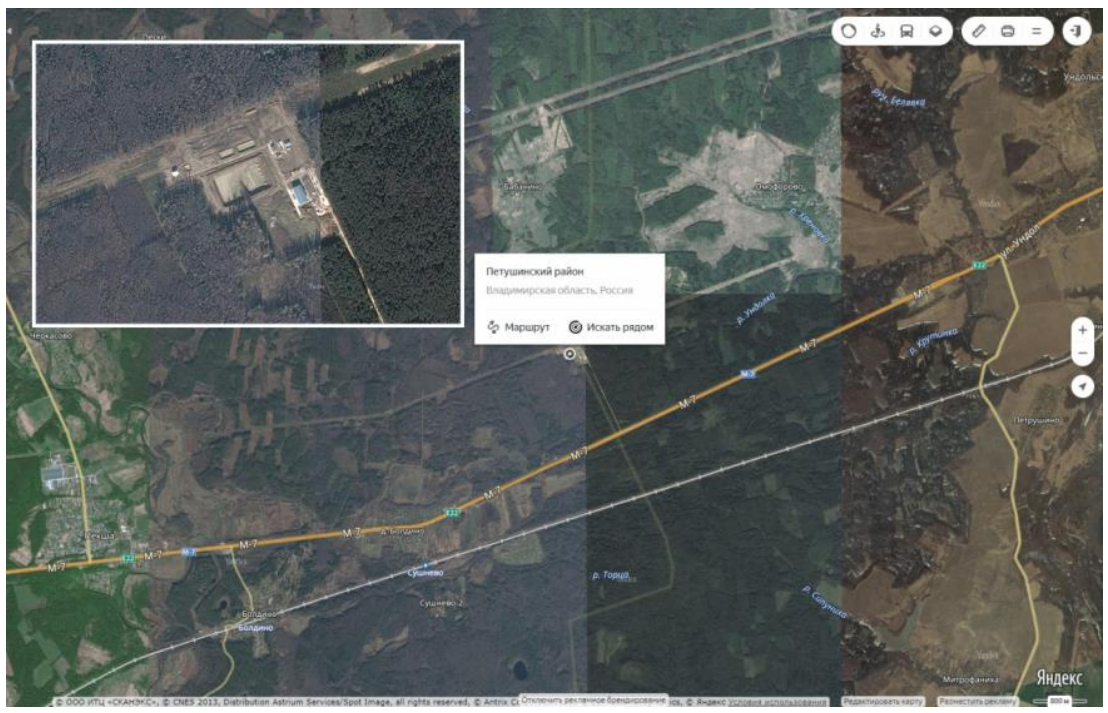

Fig. 2. The JSC "Polygon" landfill location.

The pollutant emissions calculation from the landfill was made based on the "Methodology for calculating the quantitative characteristics of atmospheric pollutant emissions from the solid municipal and industrial waste landfills" [13].

To carry out the calculation we used the data obtained including from the operating organization. The data are shown in table 2.

Table 2. The data used in the calculation

\begin{tabular}{|l|c|}
\hline \multicolumn{1}{|c|}{ Data } & Value \\
\hline Average importance of MSW & $47 \%$ \\
\hline Organic content in waste, total & $55 \%$ \\
\hline lipoid & $2 \%$ \\
\hline carbohydrate-like & $83 \%$ \\
\hline protein & $15 \%$ \\
\hline Average monthly temperature for the warm season & $15{ }^{\circ} \mathrm{C}$ \\
\hline Number of warm days & 228 days \\
\hline Duration of the warm period (more than $\left.8^{\circ} \mathrm{C}\right)$ & 5 months \\
\hline Duration of the cold period (from $0^{\circ} \mathrm{C}$ to $8^{\circ} \mathrm{C}$ ) & 7 months \\
\hline Amount of waste disposed per year & 365000 tons \\
\hline Start of landfill operation & 2015 year \\
\hline End of landfill operation & 2022 year \\
\hline
\end{tabular}




\section{Results and discussion}

As a result of the calculation made on the Methodology basis, the specific yield of the landfill gas was $0.17 \mathrm{~kg} / \mathrm{kg}$ of waste. Moreover the complete fermentation period of the waste organic part is 20 years.

Main characteristics:

- the quantitative LG output - $8.6 \mathrm{~kg} / \mathrm{t}$ of waste per year;

- the methane percentage in the total LG volume - 52.9\%.

Also table 3 shows the values of the maximum one-time and the gross emissions of LG components.

Table 3. Maximum single and gross emissions of landfill gas components.

\begin{tabular}{|l|c|c|}
\hline \multicolumn{1}{|c|}{ Component } & Maximum single emission, g/s & Gross emission, t/year \\
\hline Methane & 420.61 & 15585.63 \\
\hline Toluene & 5.75 & 212.95 \\
\hline Ammonia & 4.24 & 156.99 \\
\hline Xylene & 3.52 & 130.48 \\
\hline Carbon Monoxide & 2.00 & 74.22 \\
\hline Nitrogen dioxide & 0.88 & 32.69 \\
\hline Formaldehyde & 0.76 & 28.28 \\
\hline Ethylbenzene & 0.76 & 27.98 \\
\hline Sulfur anhydride & 0.56 & 20.62 \\
\hline Hydrogen sulfide & 0.20 & 7.66 \\
\hline
\end{tabular}

During the 5 years of the landfill's operation the gross methane emission amounted to 77928 tons. Given that from $1.6 \mathrm{~m}^{3}$ of methane $1 \mathrm{~kg}$ of haprin is obtained, from the landfill gas of the JSC "Polygon" landfill would be possible to produce 72889.9 tons of haprin (taking into account methane losses of 30\% with gases) from 2015 to 2019.

The cost of production of $1 \mathrm{~kg}$ haprin is 41070 rubles taking into account the raw materials cost, wages, amortization and other additional costs. At the same time the market price of $1 \mathrm{~kg}$ haprin is 90000 rubles. In this regard the economic benefit in the high-protein product production from the methane of the landfill is about 713 million rubles per year or 3.567 billion rubles over five years.

\section{Conclusion}

The methane using from the landfill as the main product for the haprin production is due to the significant annual volume of LG formation, minimizing the landfill's negative impact on the environment, the high quality of the resulting feed product as well as economic benefits.

The research was supported financially by Russian Foundation for Basic Research (Project No. 1701-00693a). The publication has been prepared with the support of the "RUDN University" Program $5-100$.

\section{References}

1. U. Lee, J. Han, M. Wang, J. of Cleaner Prod., 166, 335-342 (2017)

2. S.P.Bulgakov, N.N. Gavrilov, Innovation: prospects, problems, achievements:, 192197 (Plekhanov RUE, Moscow, 2013) (in Russian) 
3. A.Y. Vinarov, Current trends in science and technology, 2-2 (2017) (in Russian)

4. M. Aresta Carbon Dioxide as Chemical Feedstock, 417 (2010)

5. E.S. Klevanova, M.D. Kharlamova, International Research Journal, 135-140 (PFUR, Moscow, 2016) (in Russian)

6. Ya.I Vaysman, S.V. Maksimova, Management of methanogenesis at landfills, 235 (Permian, 2003) (in Russian)

7. Ya.I.Vaysman, Waste management. Sewage and biogas of landfills, 259 (Perm national polytechnic university, Permian, 2012) (in Russian)

8. A.A. Larionova, V.V. Filatov, Ecology, 108, 571-578 (2018) (in Russian)

9. H. Omar, S. Rohan, International Journal of Greenhouse Gas Control, 58, 159-168 (2017)

10. P.A. Trubayev, O.V. Verevkin, B.M. Grishko, Energy Systems, 436-443 (Belgorod, 2017) (in Russian) 